\title{
Do terrestrial isopods from Vâlsan River protected area reflect the region's peculi- arities? Zoogeographic and conservative implications of a possible answer
}

\section{Sára Ferenţi \& Severus-Daniel Covaciu-Marcov}

Keywords: endemic species, peculiarities, humid zones, Vâlsan, anthropic impact, protected area

\section{Abstract}

Vâlsan River valley has proved to be a refuge for different animal groups. As a consequence of its importance, we investigated the terrestrial isopods from the area, using the direct collecting method, in the years 2010-2015 and encountered 21 species. Three of them, Hyloniscus motasi, Trachelipus ater and Cylisticus transsilvanicus, are endemic in Romania, underlining the region's zoogeographical peculiarities. We divided the region into three sections (upper, middle and lower), which differ as a result of their different human disturbance. The upper section, which is less affected and without villages, conserves the native isopod fauna better. It has the highest diversity and species richness, the endemic ones being present here. In the middle and lower sections, with settlements, the native terrestrial isopod species' habitats are more limited, the anthropic changes facilitating the advance of some anthropophilous species, even introduced ones. The presence of endemic species for Romania increases the conservative value of the region. The endemic species occupy restricted, natural, humid and forested habitats, underlining their conservative importance.
Profile

Protected area

Vâlsan River valley

Mountain range

Southern Carpathians

Country

Romania

\section{Introduction}

The zoogeographical importance of terrestrial isopods has been discussed in recent years (Tăbăcaru \& Giurgincă 2013; Ferenți \& Covaciu-Marcov 2014). They joined other groups in indicating the zoogeographic peculiarities of some regions (Ferenți et al. 2012, 2013a, b). The Vâlsan River basin natural protected area has biogeographical particularities, the endemic fish Romanichthys valsanicola surviving here (see in: Telcean et al. 2011). In addition, the region's particularities, explained by its past, were observed in other groups (Covaciu-Marcov et al. 2014). The Vâlsan basin as well as other Carpathian areas seem to be zones of refuge (see in: Varga 2010). In this context we hypothesized that terrestrial isopods can contribute to revealing the region's zoogeographical importance. Also, we assumed that species composition, richness and diversity change along an altitudinal and disturbance gradient. To our knowledge, detailed studies of isopods in the Vâlsan River basin have not been carried out, only one endemic species, Trachelipus ater, being mentioned in Vâlsan Gorge (Tomescu et al. 2015). This species was also reported in the neighbouring Argeş River basin (Schmidt 1997). Information on terrestrial isopod assemblages in the Southern Carpathians are available for the Piatra Craiului Mountains (Giurgincă et al. 2006) and the Jiului Gorge (Tomescu et al. 2011). We aimed to analyse the terrestrial isopod fauna from the Vâlsan River basin, observing both its composition and particularities as well as its conservative role in a protected area.

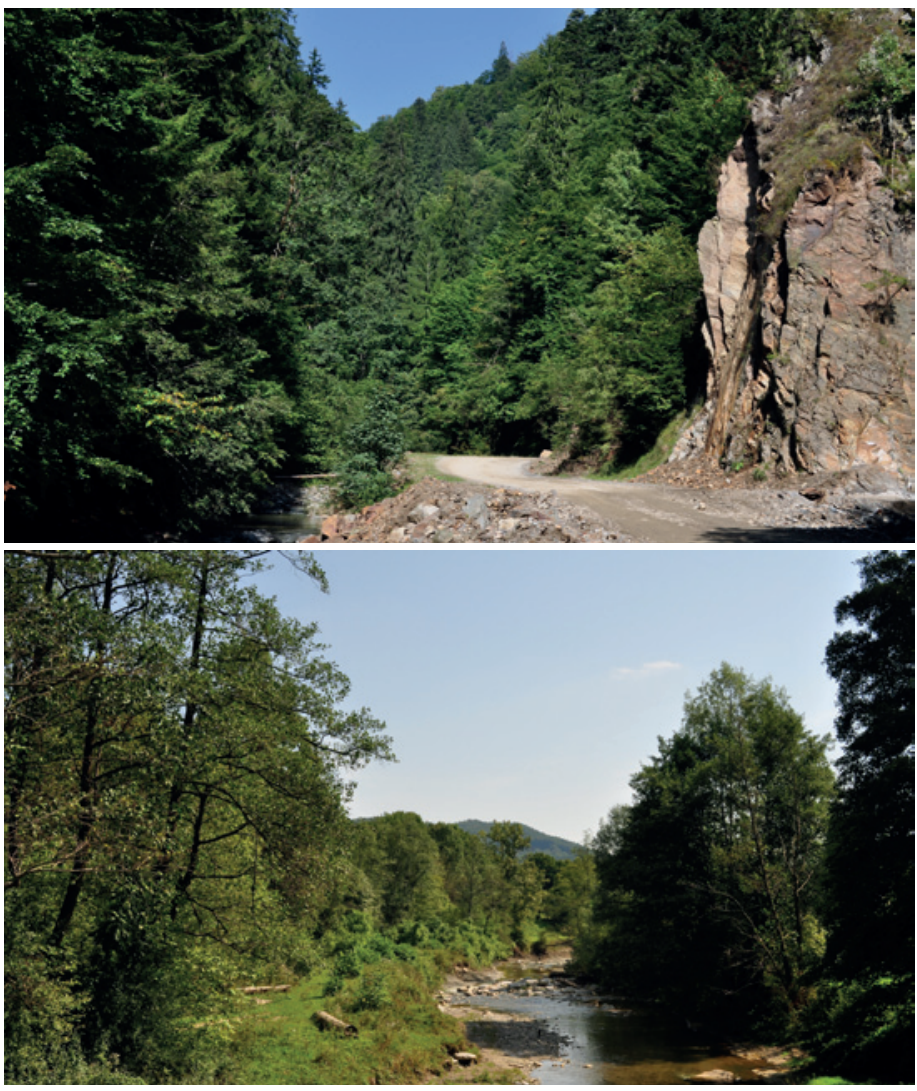

Figure 1 - The upper section (Valsan Gorge) (top) and the middle section (below) of the Valsan River, situated in the Făgaras Mountains, Southern Carpathians. (C) Covaciu-Marcov Severus-Daniel 


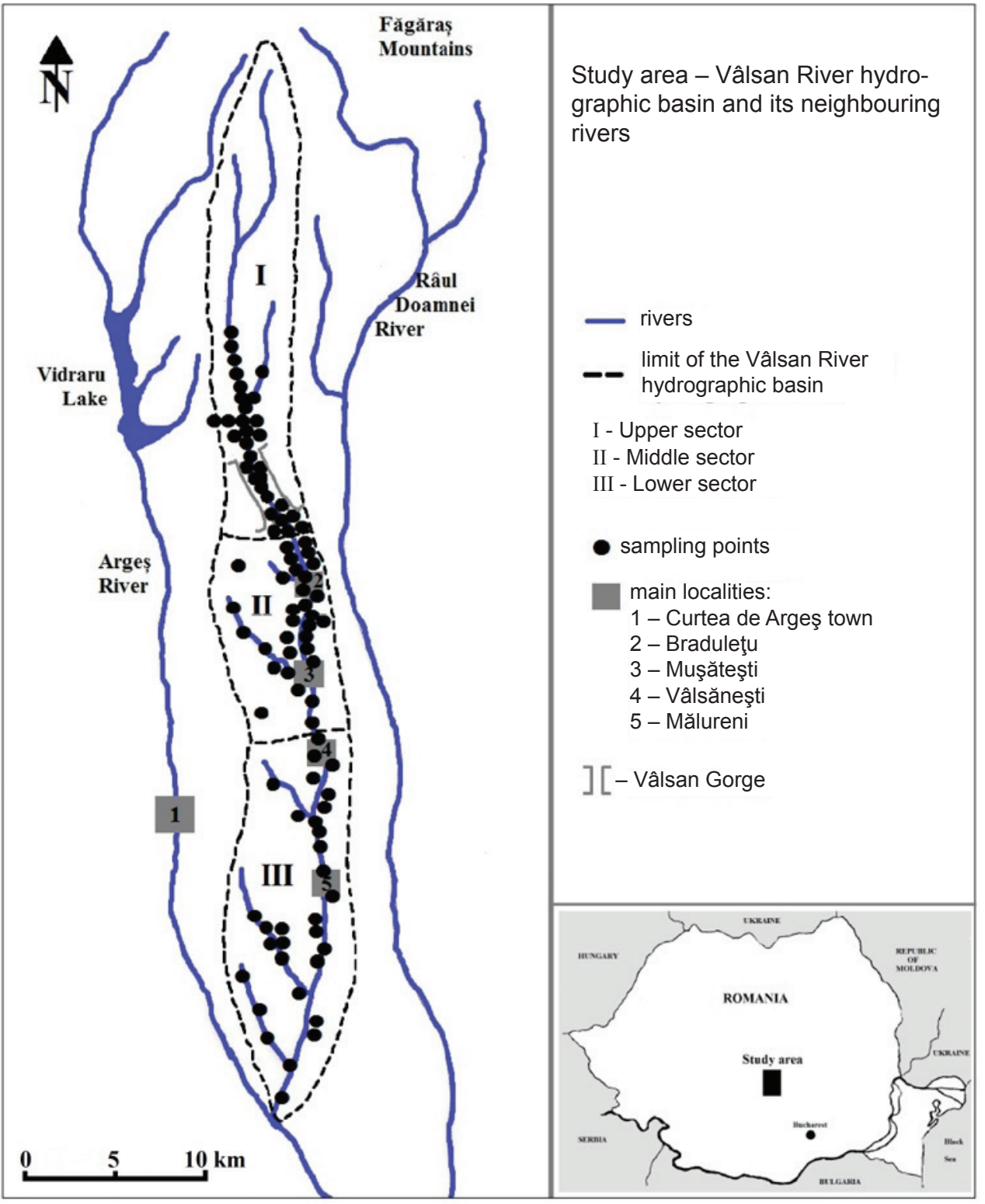

Figure 2 - The location of the study area in Romania and in the Arges River hydrographic basin.

\section{Materials and methods}

\section{Study area}

The Vâlsan River is a tributary of Argeş River, situated in the Făgăraş Mountains, Southern Carpathians (Tufescu 1986). The upper river section crosses the Făgăraş Mountains and the Ghițu Mountains, the middle part flows through Muscelele Argeşului, which belongs to the Sub-Carpathians, and the lower course crosses Gruiurile Argeşului (Posea \& Badea 1984). On leaving the mountain area, the river crosses the Vâlsan Gorge. The Vâlsan River, which starts in the Făgăraş Mountain at $2310 \mathrm{~m}$ a.s.l. (Ujvári 1972), flows into the Argeş River at approximately $300 \mathrm{~m}$ altitude. We collected isopods from the river confluence with Argeş through to an elevation of approximately $1100 \mathrm{~m}$ a.s.l. The study area was divided into three sections: 1 . the upper section, overlapping with the mountain area, down to the river's outflow from the gorge; 2 . the mid- dle section in the Sub-Carpathians; 3. the lower section, situated in the hilly area (Figure 2). In the upper section there are no settlements, human impact manifests itself in clearings and tourism (Covaciu-Marcov et al. 2014). In the other two sections numerous settlements are strung along the river (e.g. Telcean et al. 2011), the region being anthropogenically affected and heavily deforested (Badea 2011).

In each section we investigated a large variety of habitats. The upper section contains the less disturbed zones, especially in the Vâlsan Gorge. In this area we investigated swamps, streams, a sulfurous spring, ponds, an abandoned mine, abandoned buildings, camping zones, alder, beech or beech / spruce forest. In the middle section the habitats become characteristic for a rural zone, including roadsides, buildings nearby, but also wet zones near the river and forests. The lower section is apparently anthropogenically affected in the same way as the middle section, the relief 
Table 1 - The percentage abundance (A), frequency of occurrence (f), species richness, number of endemic species and Shannon Wiever diversity of terrestrial isopod species in the Vâlsan River basin (W-wetland, $C$ - cavernicolous, EN-endogeous, EUeuritopic, SI - sinanthropic, F- forest, ? - not established).

\begin{tabular}{|c|c|c|c|c|c|c|c|c|c|}
\hline \multirow{2}{*}{ Species } & \multirow{2}{*}{$\begin{array}{l}\text { Preferred } \\
\text { Habitat }\end{array}$} & \multicolumn{2}{|c|}{ Upper section } & \multicolumn{2}{|c|}{ Middle section } & \multicolumn{2}{|c|}{ Lower section } & \multicolumn{2}{|l|}{ Total } \\
\hline & & $\mathbf{A} \%$ & f\% & $\mathbf{A} \%$ & f\% & $\mathbf{A} \%$ & f\% & $\mathrm{A} \%$ & f\% \\
\hline Ligidium hypnorum & W & 6.83 & 16.13 & 9.37 & 22.58 & 1.97 & 12.90 & 3.27 & 17.20 \\
\hline Ligidium germanicum & W & 4.35 & 16.13 & 1.78 & 6.45 & 1.97 & 3.23 & 2.93 & 8.60 \\
\hline Hyloniscus riparius & W & 2.48 & 9.68 & 9.82 & 32.26 & 20.69 & 32.26 & 9.61 & 24.73 \\
\hline Hyloniscus transsilvanicus & W & 13.04 & 38.71 & 13.39 & 32.26 & 2.46 & 9.68 & 10.28 & 26.88 \\
\hline Hyloniscus motasi & $?$ & 5.28 & 3.23 & - & - & - & - & 2.26 & 1.07 \\
\hline Trichoniscus sp. & $?$ & 1.24 & 6.45 & 0.45 & 3.23 & - & - & 0.66 & 3.22 \\
\hline Mesoniscus graniger & C, EN & - & - & 1.79 & 3.23 & - & - & 0.53 & 1.07 \\
\hline Haplophthalmus danicus & W & - & - & - & - & 4.93 & 3.23 & 1.33 & 1.07 \\
\hline Haplophthalmus mengii & W? & 1.24 & 3.23 & 8.93 & 12.90 & - & - & 3.20 & 5.37 \\
\hline Cylisticus convexus & $\mathrm{EU}, \mathrm{SI}$ & 0.31 & 3.23 & 3.57 & 9.68 & - & - & 1.20 & 4.30 \\
\hline Cylisticus transsilvanicus & W, F & 3.11 & 6.45 & 0.89 & 6.45 & - & - & 1.60 & 4.30 \\
\hline Protracheoniscus politus & $\mathrm{F}$ & 1.86 & 12.90 & 4.91 & 9.68 & 4.43 & 6.45 & 3.47 & 9.67 \\
\hline Porcellium conspersum & W & 12.11 & 12.90 & - & - & - & - & 5.20 & 4.30 \\
\hline Trachelipus ater & $\mathrm{F}$ & 5.28 & 12.90 & - & - & - & - & 2.26 & 4.30 \\
\hline Trachelipus difficilis & $\mathrm{F}$ & 10.56 & 22.58 & 1.78 & 9.68 & 0.99 & 6.45 & 5.34 & 12.90 \\
\hline Trachelipus arcuatus & $\mathrm{F}$ & 27.95 & 45.16 & 26.33 & 51.61 & 31.53 & 58.06 & 28.43 & 51.61 \\
\hline Trachelipus rathkii & EU & 2.79 & 12.90 & 3.12 & 12.90 & 4.93 & 3.23 & 3.47 & 9.67 \\
\hline Porcellionides pruinosus & $\mathrm{EU}, \mathrm{SI}$ & - & - & - & - & 3.44 & 9.68 & 0.93 & 3.22 \\
\hline Porcellio scaber & $\mathrm{EU}, \mathrm{SI}$ & 0.31 & 3.23 & - & - & 7.38 & 9.68 & 2.13 & 4.30 \\
\hline Porcellio spinicornis & $\mathrm{SI} ?$ & - & - & - & - & 0.49 & 3.23 & 0.13 & 1.07 \\
\hline Armadillidium vulgare & $\mathrm{EU}, \mathrm{SI}$ & 1.24 & 3.23 & 13.84 & 48.39 & 14.78 & 38.71 & 8.67 & 30.10 \\
\hline \multicolumn{2}{|l|}{ Species richness } & \multicolumn{2}{|c|}{17} & \multicolumn{2}{|c|}{14} & \multicolumn{2}{|c|}{13} & \multicolumn{2}{|c|}{21} \\
\hline \multicolumn{2}{|l|}{ No. of endemic species } & & & \multicolumn{2}{|c|}{-} & \multicolumn{2}{|c|}{ 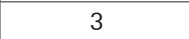 } \\
\hline \multicolumn{2}{|l|}{ Diversity $(\mathrm{H})$} & \multicolumn{2}{|c|}{2.31} & \multicolumn{2}{|c|}{2.21} & \multicolumn{2}{|c|}{2.03} & \multicolumn{2}{|c|}{2.50} \\
\hline
\end{tabular}

is softer. The investigated habitats here are streams, roadsides, ponds, beech/oak forest, etc. There are altitudinal differences between the three sections, the upper one ranges from 680 to $1100 \mathrm{~m}$, the lower one from 320 to $470 \mathrm{~m}$.

\section{Sampling methods}

The study was carried out in the years 2010-2015. Sampling was done directly at different representative points in the area. In the six study years we spent 19 days in the field. From each section (upper, middle, lower) we collected samples from 31 locations. Sampling was performed in two ways. In all the 93 investigated points the samples were collected directly with tweezers under the available shelters. We spent 20-30 minutes on each sample. In forests we used the litter sieve. The isopods were conserved and determined in the laboratory using the specialty literature for diagnosis (Radu 1983, 1985) and present nomenclature (Schmalfuss 2003).

\section{Statistics}

To estimate if the sample size was sufficient, the individual rarefaction was calculated, using Past.3x free software (Hammer et al. 2001). The data were analysed comparatively, taking into account the percentage abundance, frequency, diversity and species richness from each section. The similarity between section was estimated with the Jaccard index. For the significance of the differences between sections we used the Mann-Whitney U test (Zar 1999) calculated with Past.3x (Hammer et al. 2001). With the same software we performed a correspondence analysis on the species on different sections.

\section{Results}

In Vâlsan River basin we identified 21 terrestrial isopod species (Table 1). The only species which could not be identified belonged to Trichoniscus genus, of which we captured only five females. In total we captured 749 individuals, $42.99 \%$ of them in the upper section, $29.90 \%$ in the middle section and $27.10 \%$ in the lower one. The relatively small number of individuals is due to the study's faunistic objective and to the direct method used. After performing the rarefaction analysis we found that we had collected enough samples for estimating the region's species diversity (the minimum number of necessary samples was 28 in the upper and lower sections and 30 in the middle one). There are differences between the number of individuals / sample between the sections, 10.38 in the upper section, 7.22 in the middle section and 6.54 in the lower one. The most important species, both by percentage abundance and frequency of occurrence, was Trachelipus arcuatus (Table 1). The Vâlsan River area has a diverse terrestrial isopod fauna, with a ShannonWeaver index of $\mathrm{H}=2.50$.

Both the terrestrial isopod species composition and their ratio differ depending on the section. The upper 


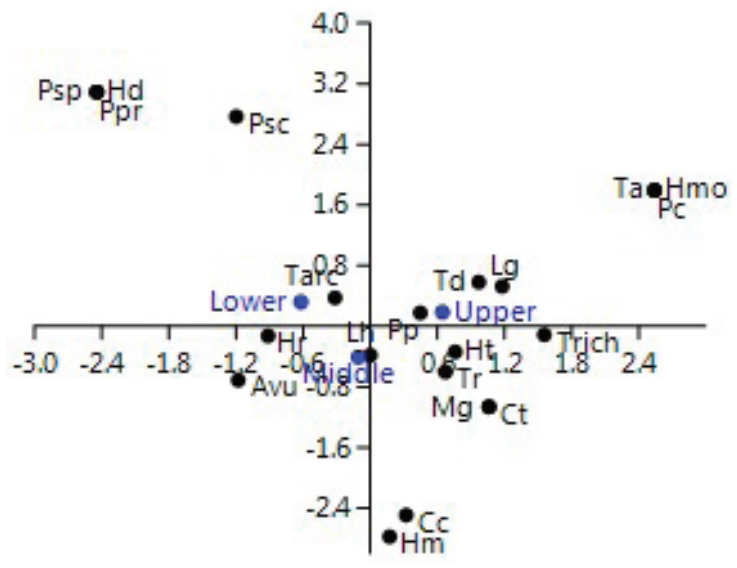

Figure 3 - Correspondence analysis between the investigated species composition from the three sections $(\mathrm{L} h-\mathrm{L}$. hypnorum, $\mathrm{Lg}-\mathrm{L}$. germanicum, $\mathrm{Hr}-\mathrm{H}$. riparius, $\mathrm{H} t-\mathrm{H}$. transsilvanicus, Hmo - H. motasi, Trich - Trichoniscus sp., $\mathrm{Mg}-\mathrm{M}$. graniger, $\mathrm{Hd}-\mathrm{H}$. danicus, $\mathrm{Hm}-\mathrm{H}$. mengii, $C c-$ C. convexus, $C t-C$. transsilvanicus, $P p-P$. politus, $P c-\mathrm{P}$. conspersum, $\mathrm{Ta}-\mathrm{T}$. ater, $\mathrm{Td}-\mathrm{T}$. difficilis, Tarc - T. arcuatus, $\mathrm{Tr}-\mathrm{T}$. rathkii, $\mathrm{P} p r-\mathrm{P}$. pruinosus, $P s c-$ P. scaber, $P s p-$ P. spinicornis, $A v u-$ A. vulgare)

section presents the highest species richness (Table 1). The same situation can also be observed for diversity (Table 1). The species overlap between assemblages is relatively reduced; according to the Jaccard index it is $72.22 \%$ between the upper and middle sections, and $50 \%$ between the lower and the other two sections. In the upper section species tied to natural habitats (forests, wetlands, floodplain forests) prevail, in the middle and lower sections species with anthropophilous tendency are present (Table 1, Figure 3). With the lower altitude the number of individuals of the Ligidium genus and Hyloniscus transsilvanicus decrease. Some sylvan species are present exclusively, or in an obviously higher number, in the higher section (e. g. Porcellium conspersum, Trachelipus ater, Trachelipus difficilis). Species with anthropogenic tendency appear exclusively or in a high number in the lower section (Porcellionides pruinosus, Porcellium scaber, Porcellium spinicornis, Armadillidium vulgare). The differences between sections were not significant according to the Mann-Whitney $U$ test ( $\mathrm{p}>0.05)$.

\section{Discussion}

The terrestrial isopod fauna from the Vâlsan section includes three species endemic in Romania, $\mathrm{Hy}$ loniscus motasi, T. ater and Cylisticus transsilvanicus. Their presence confirms the region's special characteristics also from the isopod's perspective, particuliarities proved by the endemic fish Romanichthys valsanicola (e. g. Telcean et al. 2011). T. ater is present in the central part of the Southern Carpathians in afforested areas with a gorge aspect, Vâlsan River basin being the eastern limit of its distribution range (Tomescu et al. 2015). According to older data, C. transsilvanicus and the syn- onymized C. major (see in: Schmalfuss 2003) are present in the eastern Apuseni Mountains, towards Transylvania (Radu 1951, 1985). Afterwards it was found in Bucharest (Giurgincă 2006), in eastern Transylvania (Giurgincă \& Vănoaică 2006-2007) and recently in north-western Romania, a discovery which seemed to explain its formation and distribution (Ferenți et al. 2013a). The identification of C. transsilvanicus in Vâlsan River basin, however, seems to link different parts of its apparently isolated distribution range and raises again the issue of its formation and distribution, which presently seems to be scattered. From what we saw both previously (Ferenți et al. 2013a) and in the Vâlsan area, the species is truly linked to natural areas. In the Vâlsan River basin C. transsilvanicus occur in humid sections close to the river covered with natural beech forest. We have observed many individuals near a sulphurous spring, but the species was also found in forests under fallen logs or barks. Unlike for the above species, there are very few data about $H$. motasi. Under the name of Ropaloniscus motasi it was reported once in north-western Romania in the Oaş Mountains (Radu, 1983) and subsequently considered to belong to the genus Hyloniscus (see in: Schmalfuss 2003). We have found it in a humid zone at approximately $4 \mathrm{~m}$ from the Vâlsan River. H. motasi individuals were present under fallen stones from a forest road's protective wall to $10 \mathrm{~cm}$ depth in the soil. $H$. motasi's identification in the Vâlsan Valley greatly expands its previously known distribution range, raising the issue of reconsidering the species' distribution range limits.

In terms of numbers of terrestrial isopod species, the Vâlsan River basin resembles other mountain areas in Romania, where samples were also collected directly (Giurgincă et al 2006; Tomescu et al. 2011; Ferenți et al. 2013c; Ianc \& Ferenți 2014). We encountered the same number of species as in the Pădurea Craiului Mountains (Ianc \& Ferenți 2014). Although the species composition between the two regions differs partially, in both areas sylvan and wetland species prevail. Compared to the Oaş Mountains (Ferenți et al. 2013c), there are more isopod species in the Vâlsan River basin. From Oaş many anthropophilous species are absent; if we exclude them from the Vâlsan section, the two areas would have roughly the same number of species. The Oaş Mountains thus conserve the native fauna more uniformly, which in the Vâlsan valley was maintained especially in the upper section, probably due to the intense forest clearings in the past (Badea 2011). Compared with the Jiului Gorge (Tomescu et al. 2011), the Vâlsan section presents seven more species. From Jiului Gorge the small-sized species of Haplophthalmus genus is missing (Tomescu et al. 2011). Due to their larger distribution in the country (e. g. Giurgincă 2006; Ferenți et al. 2012; Bodin et al. 2013; Ianc \& Ferenți 2014), the differences are probably coincidental. The terrestrial isopod fauna of Vâlsan seems richer than the one from the Piatra Craiului Mountains, where only six species were identified, but 
where mainly caves were investigated (Giurgincă et al. 2006). Compared to other countries, relatively few species (only 10) were encountered in the karstic area from Aggtelek National Park, Hungary (Vilisics et al. 2011), of which we found only five in the Vâlsan River basin. This fact indicates the regional differences that appear when comparing different geographical units. These differences are even more obvious in comparison with some mountain areas in Greece, where only one species is also found in the Vâlsan Valley (Sfenthourakis et al. 2012).

Of the 21 species in the Vâlsan River basin, only nine were present in all sections. Of these, four are praticolous, three sylvan and two euritopic species. The high number of species in the upper section is the consequence of the lower anthropogenic impact, but also of the fact that endemic species occur in higher sections. Three species are present only in high areas and low areas each, and just one, M. graniger, is present exclusively in the middle section. It is a mainly cavernicolous species, but endogeous populations were also registered (see in: Giurginca 2009). We found an endogeous population under stones deeply embedded in the soil, at 2-3 m from the Vâlsan River, like in other cases (Radu 1985; Giurginca 2009). According to literature data (Giurginca 2009) the species seems to have been found for the first time in the Vâlsan River basin and also in most parts of the Arges River basin. This range extension partly fills the gap between the $M$. graniger populations from the Eastern and Western Carpathians (see in: Giurginca 2009). Its exclusive identification in the middle section is probably coincidental, $M$. graniger having a much larger altitudinal distribution (Giurginca 2009), but because of its endogeous life it is more difficult to observe. If in the high area endemic species are characteristic, in the low one anthropophilous, non-native species like P. pruinosus (Cochard et al. 2010) are present. There are differences between the three sections in terms of percentage abundance and the frequency of occurrence of some species. Thus, for $A$. vulgare, a species frequent in disturbed areas (e. g. Bodin et al. 2013), the percentage abundance increases from the upper to lower sections. The situation is inversed in T. difficilis and Ligidium genus.

The differences of the terrestrial isopod fauna between the three sections can be explained both by the altitudinal differences and their different anthropogenic disturbance. Altitudinal differences in terrestrial isopods' distribution were previously reported in Romania (Tomescu et al. 2011) and other regions too (e.g. Sfenthourakis 1992; Lopes et al. 2005; Sfenthourakis et al. 2012). Sometimes, the diversity of the terrestrial isopod fauna decreased with increasing altitude (Sfenthourakis 1992), but in other cases this fact was not obvious (Sfenthourakis et al. 2012). In the Vâlsan Valley the most important area for isopods is the upper section. Still, in the case of other groups the higher mountainous region proved to be more un- favourable (Fabrizio \& Pedrini 2007). Among others, this fact was attributed to the low temperatures at high altitudes (Fabrizio \& Pedrini 2007). The thermal differences are also obvious at Vâlsan, approximately $5^{\circ} \mathrm{C}$ between the upper and lower sections (Stoenescu et al. 1966). Yet this difference does not reduce the terrestrial isopod assemblages from the upper area. But, unlike other regions with a poor upper section, the altitudinal differences at Vâlsan are smaller, not exceeding $800 \mathrm{~m}$. Moreover, on Vâlsan there are no native species in the lower sections which are absent in the upper one because of the tough climatic conditions given by the altitude. On the contrary, the native species are distributed along the entire river basin, being well represented in the upper section. The changes of the isopod fauna along the three sections are therefore not determined by the altitude. The influx of anthropophilous species indicates the cause of these differences. The anthropogenic disturbance of the middle and lower sections had restricted the habitats of the native species and permitted the access of the anthropophilous ones. In the Vâlsan River basin the differences between the sections are recent and manmade. The human development of the region has limited the available surfaces for the native species, transforming them into favourable habitats of non-native, anthropophilous species. Probably the main cause that affected the lower sections was the intense clearing activity (Badea 2011). Forest conservation seems to guarantee the endemic species' survival here as well as in other cases (e. g. Pryke \& Samways 2010).

The presence of three endemic species in Romania in the Vâlsan River basin confirms the region's peculiarities also in terms of terrestrial isopods. Isopod species seem to have taken refuge in the area, not only fish or amphibians (e.g. Telcean et al. 2011; CovaciuMarcov et al. 2014). In the case of isopods, too, the endemic species with limited distribution range are linked to natural areas with restrictive conditions. This fact does not confirm only the specificity of the Vâlsan River basin but also the possibility to use terrestrial isopods as zoogeographical indicators (Tăbăcaru \& Giurgincă 2013; Ferenți \& Covaciu-Marcov 2014). In terms of conservation, the need to protect the natural forests and humid habitats becomes obvious, as does stopping the alteration of natural landscapes. Unfortunately not a single terrestrial isopod species is protected in Romania, not even the endemic species (OUG 57/2007). The protection of rare and endemic terrestrial isopod species can currently only be realized by preserving their habitats. The story told by the terrestrial isopods highlights the conservative importance of the Vâlsan River basin as a reservoir of endemic species which still survive here.

\section{Acknowledgements}

Our study was made with the support of Freies Europa Weltanschaunng Foundation, the custodian of the 
Vâlsan River natural protected area, which we want to thank in this way. We are grateful to the anonymous reviewers for their comments that improved the manuscript quality.

\section{References}

Badea, R. 2011. The Dynamics of Forest Areas in the Vâlsan Basin. Forum geografic. Studii și cercetări de geografie şi protecția mediului 10(2): 372-378.

Bodin, A.A., S. Ferenți, R. Ianc \& S.-D. CovaciuMarcov 2013. Some data upon the herpetofauna and terrestrial isopods from Beiuș town, Romania. SouthWestern Journal of Horticulture, Biology and Environment 4(2): 137-149.

Cochard, P.-O., F. Vilisics \& E. Secher 2010. Alien terrestrial crustaceans (Isopods and Amphipods). BioRisk 4(1): 81-96.

Covaciu-Marcov, S.D., A.S. Cicort-Lucaciu, I.C. Telcean, A. Pal \& I. Sas-Kovács 2014. Some notes on the herpetofauna from Vâlsan River natural protected area, Romania. Carpathian Journal of Earth and Environmental Sciences 9(3): 171-176.

Fabrizio, S. \& P. Pedrini 2007. Biodiversity gradients in the Alps: the overriding importance of elevation. Biodiversity and Conservation 16: 3243-3254.

Ferenți, S. \& S.-D. Covaciu-Marcov 2014. Relict populations of Hyloniscus transsilvanicus and Ligidium germanicum in the Blahnița Plain, south-western Romania. Spixiana 37(1): 69-72.

Ferenți, S., D. Cupşa \& S.-D. Covaciu-Marcov 2012. Ecological and zoogeographical significance of terrestrial isopods from the Carei Plain natural reserve (Romania). Archives of Biological Sciences, Belgrade 64 (3): 1029-1036.

Ferenți, S., D. Cupșa, E.H. Sas-Kovács, I. Sas-Kovács \& S.-D. Covaciu-Marcov 2013a. The importance of forests and wetlands from the Tur River natural protected area in conservation of native terrestrial isopod fauna. North-Western Journal of Zoology 9(1): 139-144.

Ferenți, S., D. Cupșa, A.-Ș. Cicort-Lucaciu \& S.-D. Covaciu-Marcov 2013b. Winter activity of terrestrial isopods from thermal habitats in western Romania. Archives of Biological Sciences, Belgrade 65(2): 795-800.

Ferenți, S., E.H. Sas-Kovács, I. Sas-Kovács \& S.-D. Covaciu-Marcov 2013c. Data upon the terrestrial isopod fauna from the western slope of Oas Mountains, Romania. Entomologica Romanica 18: 5-10.

Giurgincă, A. 2006. On some Oniscidea and Diplopoda from Bucharest, Romania. Archives of Biological Sciences, Belgrade 58(1): 31-35.

Giurginca, A. 2009. Aspects concerning the genus Mesoniscus - morphology, spreading, historical biogeography. Bucuresti.

Giurgincă, A. \& L. Vănoaică 2006-2007. Data concerning the Oniscidea and the Diplopoda from the Varghisului Gorge Complex Reserve. Travaux du Mu- séum National d'Histoire Naturelle „Grigore Antipa” 45-46: $51-58$.

Giurgincă, A., A. Nae \& I. Popa 2006. Oniscidea (Isopoda, Malacostraca) from the Piatra Craiului National Park in Romania. Archives of Biological Sciences, Belgrade 58(1): 25-29.

Hammer, Ø., D.A.T. Harper \& P.D. Ryan 2001. PAST: Paleontological statistics software package for education and data analysis. Palaeontologia Electronica 4(1): 9 .

Ianc, R.M. \& S. Ferenți 2014. Data upon the terrestrial isopod assemblages from Pădurea Craiului Mountains karst area, western Romania. North-Western Journal of Zoology 10 (Supplement 1): 87-93.

Lopes, E.R., M. de Souza Mendonca Jr., G. BondBackup \& P.B. Araujo 2005. Oniscidea diversity across three environments in an altitudinal gradient in northeastern Rio Grande do Sul, Brazil. European Journal of Soil Biology 41(3-4): 99-107.

Posea, G. \& L. Badea 1984. România, Harta Unităților de relief (Regionarea geomorfologică). Ed. Ştiințifică şi Enciclopedică, Bucureşti. [in Romanian].

Pryke, J.S. \& M.J. Samways 2010. Significant variables for the conservation of mountain invertebrates. Journal of Insect Conservation 14: 247-256.

Radu, V.G. 1951. Specii de Cylisticus (Isopode terestre) în fauna Republicii Populare Române. Buletin Științific, Secțiunea de Științe Biologice, Agronomice, Geologice si Geografice 3(4): 739-749. [in Romanian]

Radu, V.G. 1983. Fanna R. S. R. Crustacea. vol. IV, Fascicola 13 Ordinul Isopoda, Subordinul Oniscoidea, Oniscoidee inferioare. Ed. Academiei R. S. R. Bucharest. [in Romanian].

Radu, V.G. 1985. Fauna R. S. R. Crustacea. vol. IV, Fascicola 14 Ordinul Isopoda, Subordinul Oniscoidea, Crinochaeta. Ed. Academiei R. S. R. Bucharest. [in Romanian].

Schmalfuss, H. 2003. World catalogue of terrestrial isopods (Isopoda: Oniscidea). Stuttgarter Beiträge zur Naturkunde, Serie A 654: 1-341.

Schmidt, C. 1997. Revision of the European species of the genus Trachelipus Budde-Lund, 1908 (Crustacea: Isopoda: Oniscidea). Zoological Journal of the Linnean Society 121: 129-244.

Sfenthourakis, S. 1992. Altitudinal effect on species richness of Oniscidea (Crustacea; Isopoda) on three mountains in Greece. Global Ecology and Biogeography Letters 2: 157-164.

Sfenthourakis, S., D. Skouras \& Y. Anastasiou 2012. A comparison of terrestrial isopod communities among different habitat types on $\mathrm{mt}$. Chelmos (Peloponnisos. Greece). Journal of Biological Research-Thessaloniki 18: 198-204.

Stoenescu, Ş.M., A. Şchiop, I. Dica, E. Popescu, E. Patrichi \& E. Țepeş 1966. Atlasul climatologic al R. S. R., Bucureşti

Tăbăcaru, I. \& A. Giurgincă 2013. Cavernicolous Oniscidea of Romania. Travaux de l'Institut de Spéologie "Émile Racovitra" 52: 3-26. 
Telcean, I.C., A.S. Cicort-Lucaciu, I. Sas \& S.-D. Covaciu-Marcov 2011. Romanichthys valsanicola is still fighting! How can we help? North-Western Journal of Zoology 7(2): 334-338.

Tomescu, N., S. Ferenti, L.A. Teodor, S.-D. Covaciu-Marcov, A.-S. Cicort-Lucaciu \& F.N. Sucea 2011 Terrestrial isopods (Isopoda: Oniscoidea) from Jiului Gorge National Park, Romania. North-Western Journal of Zoology 7(2): 277-285.

Tomescu, N., L.A. Teodor, S. Ferenti \& S.-D. Covaciu-Marcov 2015. Trachelipus species (Crustacea, Isopoda, Oniscidea) in Romanian fauna: morphology, ecology, and geographic distribution. North-Western Journal of Zoology: accepted.

Tufescu, V. 1986. Harta R. S. România. Editura Didactica şi Pedagogica, Bucureşti. [in Romanian].

Ujvári, I. 1972. Geografia apelor României. Bucuresti. [in Romanian].

Varga, Z. 2010. Extra-Mediterranean refugia, postglacial vegetation history and area dynamics in eastern Central Europe. In: Habel, J.C. \& T. Assman (eds.), Relict species: phylogeography and conservation biology: 57-87. Berlin, Heidelberg.

Vilisics, F., P. Sólymos, A. Nagy, R. Farkas, Z. Kemencei \& E. Hornung 2011. Small scale gradient effects on isopods (Crustacea: Oniscidea) in karstik sinkholes. Biologia, Section Zoology 66(3): 499-505.
Zar, J.H. 1999. Biostatistical analysis. $4^{\text {th }}$ Edition. New Jersey, Prentice Hall.

O.U.G. 57/2007. Ordonanta de urgenta 57/2007 privind regimul ariilor naturale protejate, conservarea habitatelor naturale a florei si faunei salbatice [in Romanian].

\section{Authors}

\section{Sára Ferenti}

studies terrestrial isopods in Romania. She is interested in their geographical distribution, ecology and the particularities of the isopod fauna from areas with zoogeographical importance. University of Oradea, Faculty of Sciences, Department of Biology, Universitatii str. 1, 410087 Oradea, Romania; "Iosif Vulcan" National College, Jean Calvin str. No. 3, Oradea, Romania.E-mail: ferenti.sara@gmail.com

\section{Severus-Daniel Covaciu-Marcov}

is interested in zoogeography of Romania, especially the herpetofauna, but also other groups with high biogeographic value. He also studies invasive species and biodiversity conservation. University of Oradea, Faculty of Sciences, Department of Biology, Universitatii str. 1, 410087 Oradea, Romania. 